\title{
AHMED-İ DÂT İLE İLGİLİ YENİ BİLGİLER
}

\author{
Tunca Kortantamer
}

Türk Edebiyatının Eski Anadolu Türkçesi alanındaki büyük yazarlarından birisi olan Ahmed-i Dâê, çağdaş araştırıcılarca önceleri pek önemsenmediği gibi, yanlış da değerlendirilmişti. Bunun başta gelen nedenleri arasında Dâcînnin en önemli eserleri olan Türkçe divanı ve Çengnâme'sinin yüzyılımızın ilk yarısının sonlarına kadar ele geçmemiş oluşu gösterilebilir. Dâ‘̂ nin gerçek değerini en iyi ortaya koyan bu eserler uzun süre bulunamadıkları için, Osmanlı kaynaklarından çoğunun Dâê̂ ile ilgili, doğru olmayan değerlendirmeleri bir zincirin halkaları gibi çağımıza ulaşıp geldiler. Latîfî ve Hasan C.elebi ile başlayan bu yanılgıların izleri Gibb, Köprülü ve Bombaci gibi tanınmış edebiyat tarihçilerinde bile göze çarpıyor ${ }^{1}$.

Divanın olsun, Çengnâme'nin olsun ilk nüshalarını, bölümleri biribirine karışmış bir külliyât biçiminde, Prof. Ahmet Ateş, Burdur'da buldu. Prof. A. Ateş bulduğu yazmanın eksikleri olduğunu belirtmekle birlikte, Dâê̂’nin pek azı bilinen şiirlerinin büyük bir çoğunluğunun ortaya çıtığı inancındaydı ${ }^{2}$. Buna karşılık, Ahmed-i Dâề’nin gerçek değerini araştırma dünyasına tanıtan Prof. İ. H. Ertaylan, onun divanının önemli bir bölümünün ele geçmediği düşüncesini kesinlikle ortaya attığı gibi, Germiyan'daki şiirlerini içine alan şimdilik ele geçmemiş başka bir divanı olabileceğini de ileri sürdü ${ }^{3}$. Böylece

1 Ismail Hikmet Ertaylan, Ahmed-i Dâĉ, Hayatı ve Eserleri, Türk Edebiyatı Örnekleri VII, İstanbul Úniversitesi Edebiyat Fakültesi Yayınlarından Türk Dili ve Edebiyatı zümresi No: 518, İstanbul 1952, s. 50, 54, 82, 46, 47, 49; krş. Tunca Kortantamer "Der Diwan Aḅmed-i Dā'Is", ZDMG'de (= Zeitschrift der Deutschen Morgenländischen Gesellschaft) şımasını bekliyoruz.

2 Ahmet Ateş, "Burdur-Antalya ve havalisi kütüphanelerinde bulunan Türkçe, Arapça ve Farş̧a bazı mühim eserler", İstanbul Ưniversitesi Edebiyat Fakültesi Türk Dili ve Edebiyatı Dergisi, II (1948), s. 172-174.

3 I. H. Ertaylan, Ahmed-i Dâcî, s. 72-73. 
Burdur yazması uzun süre Ahmed-i Dâê̂ divanının, eksik olsa bile, elde bulunan tek nüshası olarak kaldı ${ }^{4}$.

$\mathrm{Bu}$ durumu değiștiren yeni bilgiler elde etmiş olduğumuzu bu yazımızla büyük bir mutluluk duyarak ileri sürebiliriz. Almanya'da Ahmedî üzerine doktora çalışması yaparken Kahire'de, Mısır Millî Kütüphanesi Dār al-kutub val-vas̄ā'iḳ al-ḳavimiyya'da (= eski Hुidíviyya Kütüphanesi) bulunan, Ḥılmĩ ad-Dāgistānī'nin kataloğunda adı Ahmedî divanı olarak geçtiğinden ${ }^{5}$ pek göze çarpmayan bir yazmanın Ahmed-i Dâê̂ divanının tam bir nüshası olduğunu gördük ve önce Ahmedî üzerindeki çalışmamızda araştırma dünyasına duyurduk $^{6}$. Sonra yazmayı, şu sıralarda ZDMG'de ${ }^{7}$ çıkmış olması gereken, bir yazı ile daha yakından ve daha geniş bir biçimde, Burdur yazması ile de karşılaştırarak tanıttık. Gene basılmak üzere olan ayrı bir yazımızda Kahire yazmasından yararlanarak, Ahmed-i Dâ'î'nin Mutâyebât adı altında toplanan şiirlerinin başka bir eser olmayıp, divanın bir parçası olduğunu ortaya koyduk ve bu savımızı Kahire nüshası ile Burdur nüshasını karşılaştırarak belirtmeye çalıştık $^{8}$. Önümüzdeki günlerde de Kahire yazmasının Burdur yazması ile karşılaştırmalı çeviriyazısını yayımlamayı umuyoruz.

Kahire yazmasında 2885 beyit bulunmakta, buna karşılık Burdur yazmasında, Mutâyebât da dahil olmak üzere 1535 beyit yer almaktadır. Kahire nüshasında, Burdur nüshasında bulunmayan çok sayıda kasideler, gazeller, beş tercî-i bend, bir terkîb-i bend ile iki müstezad vardır. Kahire nüshası harekeli oluşu, eksik yaprağının olmayışı, eskiliği ve iyi bir durumda bulu-

4 Fahir Iz, "Dāc1", The Encyclopedia of Islam. New Edition, Leiden/London 1954 ve öt., c. II, s. 98; Alessio Bombaci, Histoire de la littérature turque, Paris 1968, s. 251; İsmail Únver, "Cumhuriyet Döneminde Türkiye'de Yaymlanmış Divanlar Úzerine", Cumhuriyetin 50. Yıldönümünü Anma Kitabı, Ankara Üniversitesi Dil ve Tarih-Coğrafya Fakültesi, Yayın No: 239, Ankara 1974, s. 203. Divanın bu durumuna karşılık kısa bir süre sonra Çengnâme'nin tam bir nüshası ortaya çıktı, bkz., Ertaylan, Ahmed-i Dâcî, s. 79. Nedense Dâ‘'’nin gerçek değeri bilinir olduktan sonra dahi eserleri yeterince incelenmedi. Bunun bir sonucu olarak da Dâcî, bütün önemine karşlık, söz gelişi, bugün bile orta öğretim düzeyindeki kitaplarımızda yer almamaktadır.

5 CAlī Hilmī ad-Dāgiistānī, Fihrist al-kutub at-Turkiyya al-maveūda fī'l-kutubhāna alHidiviyya, Kahire 1306/1888, s. 113.

6 Tunca Kortantamer, Leben und Weltbild des altosmanischen Dichters Ahmedi unter besonderer Berücksichtigung seines Diwans, Islamkundliche Untersuchungen, Band 22, Klaus Schwarz Verlag, Freiburg im Breisgau 1973, s. 53-55.

7 Zeitschrift der Deutschen Morgenländischen Gesellschaft.

8 T. Kortantamer, "Ahmed-i Dâç̂nin 'Mutâyebât' Adıyla Tanınan Eseri Üzerine" 
nuşu dolayısıyla araștırma dünyası için değeri büyük bir yazmadır. Biz bu yazımızda yalnız, Kahire yazmasından elde ettiğimiz, yazarın yaşamı, karıştığı olaylar ve çevresi ile ilgili yeni bilgileri sunmaya çalışacağız.

Divandan Dâ'̂̂’nin doğum yeri, yılı ve öğrenimi konularında sözünü etmeğe değer yeni bir bilgi edinemediğimiz gibi, onun Aydın ve Germiyan sarayları ile ilişkisini gösterir bir ipucu da ele geçiremiyoruz. Zaten hiçbir yerde Dâê̂’nin Aydın sarayında bulunduğunu gösteren güvenilir en ufak bir delil bile yoktur ${ }^{9}$. Germiyan Beyi II. Yakub adına yazılan Tâbirnâme Tercümesi' $\mathrm{ni}^{10}$ bir yana birakacak olursak, bu delil yokluğu, Dâê̂’nin Germiyan sarayı ile ilişkileri için de geçerli sayılabilir. Hernekadar onun Germiyanlı olduğunu ve Germiyan'da kadılık yaptığını söyleyen kaynaklar varsa da11, Dâê̂'nin yirmiye yakın eserinin, Tâbirnâme Tercümesi dışında, hiç birisinde onun G€rmiyan sarayı ile ilişkisini ortaya koyacak en ufak bir iz bile görülememektedir. Divanının elimize geçen tam yazmasında da böyle bir izin göze çarpmayışı akla ister istemez, Dâê̂’nin Germiyan sarayı ile ilişkilerinin pek öyle önemli olmayabileceği düşüncesini getiriyor.

Emir Süleyman, Mehmed Çelebi, Musa Çelebi, II. Murad, Ali Paşa, Hamza Paşa gibi çok sayıda kişiler için yazılmış şiirler bulunan divanda hiçbir Germiyan beyinden açıkça anlaşılır bir biçimde söz edilmiyor ve Dâê̂’nin sayısı pek çok olan eserlerinin yavaş yavaş ortaya çıkan değişik yazmalarında Germiyan'la ilgili bir yan görülmüyor. Buna karşılık, söz gelişi, Germiyan'dan Osmanlı çevresine gelen bir Şeyhî’nin divanında Germiyan Beyi için de şiir-

9 Prof. t. H. Ertaylan, Uzun Firdevsî̀nin (doğumu 1453) Dâĉ̀ tarafindan yazılmış bir Süheyl ü Nevbahar'dan söz ettiğini söyleyip, Hoca Mesud'un tamamladığı Süheyl ü Nevbahar'ın ilk bin beyitini Hoca Mesud'un yeğeni Izzeddin Ahmed'in yazdığını göz önüne alarak, İzzeddin Ahmed ile Dâc'innin aynı kişi olabilecekleri düşüncesini ortaya atıyor. Daha sonra buna daya-

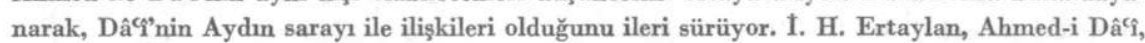
s. 3, 5-6, 10, 12. Prof. F. K. Timurtaş'ın da belirtmiş olduğu gibi, "bu düşünce çok söz götürür", F. K. Timurtaş, "Ahmed-i Dâç" TD III (1954), s. 431. Dậ́̂, gerçekten bir Süheyl ü Nevbahar yazmış olsa bile, bu onun Izzeddin Ahmed olmasını gerektirmez. Ayrica Uzun Firdevsî, Dâc' nin Süheyl ü Nevbahar yazdığın söylediğine göre, Dâc, neden Süheyl ü Nevbahar'm yalnız bin beyitini yazan İzzeddin Ahmed olsun? Sonra neden hiçbir kaynakta Dậ́̂ ile Izzeddin Ahmed'in aym kişi olduklarmı gösteren, ya da sezdiren bir belirti gözümüze ilişmiyor? Ayrıca Uzun Firdevsî yanılmış olamaz mı? Bütün bunlardan başka ve en önemlisi, Dâç kendisi Tıbb-1 Nebevî Tercemesi'nin önsözünde ismini Ahmed b. Ibrahim b. Muhammed el-maruf bi'd-Dâç diye verirken neden Izzeddin Ahmed demiyor? Bütün bu sorular 1. H. Ertaylan'ın ileri sürdüğ̈̈ düşüncenin bu durumda doğrulanamayacağın gösteriyorlar.

10 t. H. Ertaylan, Ahmed-i Dâcì s. 14-15, 161 ve öt.

11 1. H. Ertaylan, Ahmed-i Dậ́, s. 10-13. 
ler buluyoruz ${ }^{12}$; ya da bir Ahmedî'nin en azından Aydın sarayında bulunduğunu ve daha sonra İskendernâme'sini Germiyanoğlu Süleyman Bey adına yazmağa başladığını biliyoruz ${ }^{13}$.

Ahmed-i Dâĉ̂̀nin Germiyanoğlu II. Yakub için yazdığı Tâbirnâme Tercümesi'ni, onun Germiyan sarayında yaşadığını gösteren yeterli bir delil saymak sakıncalı olur; çünkü Dâ'î’nin II. Murad'ın saltanatının ilk yıllarında yaşamakta olduğu, așağıda görüleceği üzere, artık kesinlikle ortaya çıtığına göre, eser, elinin açıklığıyla ün salan II. Yakub Bey'e, 1427 yılında II. Murad'ı ziyareti ${ }^{14}$ sırasında da sunulmuş olabilir. Bundan başka, aşağıda görüleceği üzere, Osmanlı çevresinden bir ara ayrılıp, illerde dolaşmış olan Dâ'î nin kısa bir süre Germiyan'da kalıp eseri bu surada yazdığı da düşünülebilir. Bütün bu düşünceler bize, yalnız Tâbirnâme Tercümesi’ne bakıp, Dâê̂’nin Germiyan'la ilişkileri konusunda kesin yarglara varmamak gerektiğini gösteriyorlar.

Dâê̂’nin, Germiyan'da yazdığı şiirleri ayrı bir divanda toplamış olabileceği düşüncesini ise ${ }^{15}$, elde şairlerin değişik hanedanlar için değişik divanlar düzenlediklerini gösterir örnekler olmadığından, şimdilik geçerli sayamıyoruz $^{16}$.

Bütün bu yukarıda sözü edilen noktaları, hele hele divanının tam yazmasını göz önüne alarak, Dâ̂̂’nnin Aydın ve Germiyan sarayları ile ilişkilerini kesinlikle ortaya koyacak deliller bulunmadıkça, bu konudaki yargılarda çok ihtiyatlı davranmak gerekiyor.

12 F. K. Timurtaş, Şeyhî, Hayatı ve Eserlerinden Seçmeler, Isstanbul Úniversitesi Yayınlarından No: 1363, Edebiyat Fakültesi Türk Dili ve Edebiyatı Bölümü, Edebiyat Fakültesi Basımevi (Istanbul) 1968, s. 166-167, 177-179.

13 T. Kortantamer, Leben und Weltbild, s. 17-32, 42-45, 105-124.

14 Bkz., İsmail Hakkı Uzunçarşılı, Osmanlı Tarihi, Türk Tarih Kurumu yayınlarından, XIII. Seri-No. 16 a2, Ankara 1972, c. I, s. 406; krş., Mustafa Akdağ, Türkiye'nin İktisadî ve İçtimaî Tarihi 1243-1453, c. I, s. 364. Neşrî, Yakub Bey'in elinin açıklğı konusunda ilgi çekici bir hikâye anlatıyor: Yakub Bey ziyareti sırasında elindeki aveundakini bitirince II. Murad' dan yardım istemek zorunda kalmış. II. Murad bunun üzerine: "Hak tecâlâ bize bir karındaş verdi-ki, kendi memleketi hâslından gayri, bizim kazancımız dahi harena yetişmez." demiş. Neşrî, Kitab-1 Cihan-nümâ. Neşrî Tarihi. Yayınlayanlar Faik Reşit Unat, Mehmet A. Köymen (Türk Tarih Kurumu Yaymlarindan III. seri-No 2 a-b) Ankara 1957, c. II, 606-607.

15 Bkz., I. H. Ertaylan, Ahmed-i Dâcî, s. 72-73.

16 Çok çok, Ankara savaşının doğurduğu karışıklıklarda o güne kadarki şïrler kaybolmuş olabilir, ama Dâç’nin eldeki şïrlerinde ve diğer eserlerinde böyle bir şeye değinilmiyor. 
Dâê̂’nin Osmanlı saray çevresine ne zaman ayak basdı̆̆ı ve orada ilişkilerini kesintisiz sürdürüp sürdürmediği bilinmiyor ${ }^{17}$. Bu konuda ilk güvenilir bilgiyi Çengnâme'den ${ }^{18}$ elde ediyoruz. Dâ'î, 808 şevvalinde (= 1406 Mart) bitirdiği bu eserini Emir Süleyman'a sunmuştur. Emir Süleyman o sıraląrda Bursa'da bulunmaktaydı. Mehmed Çelebi ise Amasya'ya çekilmişti, bu bakımdan Dâê̂'nin de, Prof. İ. H. Ertaylan'in sandığı gibi Edirne'de olmayıp ${ }^{19}$, Emir Süleyman'la birlikte Bursa'da bulunması gerekir. Dâê̂’nin 809 yılı recebinde (= 1406 Aralık) ölen Ali Paşa için yazdığı yedi beyitlik ufak mersiye de bu düşünceyi doğruluyor ${ }^{20}$ :
'Alì Pāşā cihānuñ cānı Pāşā21
Kamu pāşālaruñ sulțānı Pāşā
Kemāl-i 'aḳlile 'ālemde meşhūr
Zarāfet gevherinüñ kānı Pāşā
Vizāret hul' atidi ḳāmetine
Beșāret defter ü dìvānı Pāşā
Şu resme țurmişidi salțanatda
Kamu tertībile erkānı Pāşā
Cemāli bedriçün gözden tolundı
Didiler iy dirīgā ḳanı Pāşā
Yerinde ḳalmadı bir yādigārı
Diyeler manṣıba erzāni Pāşã
Revānına ḳlur $\mathrm{Da}^{\mathrm{C}} \bar{c}_{\mathrm{i}}$ ducālar
Ki gāyet boş țutardı anı Pāşā

17 Yazımııın bundan sonraki bölümünde sık sık başvuracağımız tarihî genel bilgiler için aşağdaki eserlerden yararlandık: I. H. Uzunçarşı̆h, Osmanh Tarihi, c. I, s. 260 ve öt.; M. Akdağ, Türkiye'nin İktisadí ve Içctimaî tarihi, c. I; Tayyib Gökbilgin, "Süleyman Çelebi (Emir)", İslam Ansiklopedisi, c. XI, s. 179-182; 1. H. Uzunçarşıl, "Mehmed I", İslam Ansiklopedisi, c. VII, s. 496-506; Şehabettin Tekindağ, "Musa Çelebi", İslam Ansiklopedisi, c. VIII, s. 598-615; Neşrî, Cihan-nümâ, e. I, s. 311-419, c. II, s. 422-517.

18 t. H. Ertaylan, Ahmed-i Dấ, s. 79 ve öt.

19 I. H. Ertaylan, Ahmed-i Dấ, s. 11, 24.

20 Çengnâme, Ali Paşa'nın ölümünden, burada görüldüğü üzere, sekiz ay önce bitirildiğine göre, yalnız Çengnâme'ye dayanarak, I. H. Ertaylan'n yaptığı gibi, eserde adı geçen Alaeddin Mehmed Paşa'nın Ali Paşa'dan sonra onun yerine vezirâzam olduğu ileri sürülemez. Bkz., I. H. Ertaylan, Ahmed-i Dâcî, s. 106.

21 Kahire yazması, yk. 111 b, beyit 2-8. Yazmada kelimelerin arasıra yanlış harekelendiği görülmektedir. Biz burada seçtiğimiz metinlerin imlâsını değiştirmeyip, yalnız yeri geldikçe dipnotlarında durumu belirterek, kelimelerin doğrusunu verme yolunu tuttuk. 
Dâề, hernekadar Ali Paşa'nun kendisini hoş tuttuğunu söylüyorsa da, Ali Paşa'yı pek sevdiği ileri sürülemez. Emir Süleyman, Mehmed Celebi ve Hamza Paşa için yazdığı gerçekten güzel ve duygulu mersiyelerle ölçüye vurulduğunda yukarıdaki beyitler çok yavan ve duygudan yoksun kalıyorlar. Ayrıca Prof. İ. H. Ertaylan'ın, yayımladığı Türkçe divanın sonuna koyduğu, Eğridirli Hacı Kemal'in Câmi'ü'n-nezâ'ir'inden alınma, Emir Süleyman için yazılmış kasidedè22, Dâề'nin sözlerinden, Emir Süleyman'ın Ali Paşa'nın ölümüne çok üzüldüŭü ve onu teselli etmeğe çalışan Dâề’nin Ali Paşa'nun ölümünü pek de öyle önemsemediği açıkça görülmektedir. Ali Paşa'nun ölümü srrasında Emir Süleyman'ın çevresinde bulunan Dâ'î'nin onun ardından yazdıkları, daha çok, Emir Süleyman'a yaranmak için söylenmişe benziyor ${ }^{23}$.

Kahire yazmasında Emir Süleyman için yazlmış, hiç birisi Burdur yazmasında bulunmayan, birisi mersiye olmak üzere on bir şiir yer alıyor ${ }^{24}$. Bunlardan, Dâcî̀nin Emir Süleyman'la ilişkileri ve o sıralardaki yaşantısı konusunda ilgi çekici bilgiler edindiğimiz gibi, şehzadeler arasındaki çatı̧̧maların havasını da koklayabiliyoruz ${ }^{25}$.

$22 \mathrm{Bu}$ kaside Kahire yazmasinda yoktur.

23 Ahmedî'nin de Ali Paşa'ya karşı buna benzer bir tutum içinde olabileceğini gösterir işaretlerin varlığı göz önüne alınınea Ali Paşa'nın, Emir Süleyman'ın çevresindeki şairlerle ilişkisi açısından ilgi çekici bir durum ortaya çkıyor, bkz., T. Kortantamer, Leben und Weltbild, s. 169-171.

24 Kaside ve tercî-i bendlerden oluşan bu şïlerin üç tanesinden alınan yedişer beyitlik dört küçük parça Burdur yazmasında gazeller arasında yer alyyor. Bkz., Kahire yazması, yk. 12 b, beyit 1-6, yk. 13 b, beyit 5, krş., 1. H. Ertaylan, Ahmed-i Dâci (Tıpkıbasım), s. 81, beyit 8-12, s. 82, beyit 1-2; Kahire yazması, yk. 17 b, beyit 1-6, yk. 18 b, beyit 7, krş., I. H. Ertaylan, Tıpkıbasım, s. 26, beyit 5-11; Kahire yazması, yk. 25 b, beyit 11-13, yk. 26 a, 1-3, 11, krş. İ. H. Ertaylan, Tipkabasım, s. 49, beyit $8-12$, s. 50, beyit 1-2; Kahire yazması, yk. 27 a, beyit 1-5, 13, yk. 27 b, beyit 1, krş., I. H. Ertaylan, Tıpkıbasım, s. 20, beyit 9-10, s. 21, beyit 1-5.

25 Emir Süleyman için yazıldığm ileri sürdüğümüz şiirlerin bir ikisinin, Ahmedî’de olduğu gibi, Germiyanoğlu Süleyman Şah için yazılı yazlmadığı tartışma konusu edilebilir, bkz. T., Kortantamer, Leben und Weltbild, s. 122. Biz bu şïrlerin hepsinin Emir Süleyman için yazıldiğı inancındayız. Bizi böyle düşünmeğe aşağıdaki özellikler yöneltiyor: Şiirlerin hiç birisinde Germiyan'la, Germiyanoğlu'yla ilgili bir işaret yoktur. Bir bölümünde ya Osmanh ülkesinin, ya da Emir Süleyman'ın atalarının adı geçiyor. Büyük bir çoğunluğunda taht kavgalarının izleri bulunuyor. Hemen hepsi şaraptan ve şarap meclisinden Emir Süleyman'ın tarihî kişiliğine uygun bir biçimde söz ediyorlar. Bu özellikler, Ahmeḑ’nin Emir Süleyman için yazdığı şiirlerde de görülüyor. Buna karş̧ılık, her iki şairin de, söz gelişi, Mehmed Çelebi için yazdıklan şiirlerde ağırlk noktası ve bu hava değişiyor, Ahmedî için bkz., T. Kortantamer, Leben und Weltbild, s. 174 ve öt. 
Söz gelişi, Dâê̂ aşağıdaki kasidede önce, Emir Süleyman için yazdığı diğer şiirlerinin hemen hemen hepsinde olduğu gibi, içkili ve sazlı sözlü eğlenceleriyle tanınan ve ölümü de bu yüzden olan koruyucusunun seveceği biçimde, içkiden söz ediyor. Daha sonraki beyitlerinde ise, günün sultan oğlu sultan Emir Süleyman devri olduğunu, devlet tacinın, din tahtının onunla övündüklerini, din ve devletin itibar bulduğunu, adına hutbe okunup, sikke kestirildiğini söylüyor. Saltanat olsun, devlet olsun Emir Süleyman'a miras kalmıştır ve onun adaleti ile yeryüzü güven veren bir yer olmuştur:

Feraḥ gelsün teraḥ gitsün gül açılsun mül içilsün ${ }^{26}$

Dirilsin Cakll-ı cān andan düzilsün kārbār andan

İç ol sāḳi elinden kim yanag̀ı 'aksi cām içre

Düşer gül-reng olur bāde utanur lālezār andan

Ferag u emn ü sıḥ̣hatdür bu furșat key ganīmetdür Sacādet hōō devletdür iş olubdur bahtiyār andan ${ }^{27}$

Bugün kim ḳutlu devrāndur buṣūṣā devr-i Sulțāndur Ki sultān ibni sulțāndur hem oldur şehriyār andan

Şehinşeh Mìr Selmān ${ }^{28}$ kim Süleymān-1 zemān oldur $\mathrm{Ki}$ devlet tāeı dīn tahtı iderler iftihār andan

Anuñ adıyıla zinnet bulubdur huțe vü sikke Zirä kim dīnle devlet bulurlar ictibār andan

Saña mînāsdur aṣl-1 sa'ādet salțanat devlet Zeht devletlü cān ol kim özüñdür yādigār andan

Bugün 'adlün̄ zamānında cihān dārü'l-amān oldı Ki şerc ü dīn-i İslām uş bulubdur iştihār andan

26 Kahire yazması, yk. 12 b, beyit 5-10; yk. 13 a, beyit 11-12. Burada verilen ilk iki beyit Burdur yazmasında da yer almaktadır, bkz., I. H. Ertaylan, Ahmed-i Dâç (Tipkıbasım), s. 81, beyit 12 , s. 82 , beyit 1 .

27 Misra vezin bakımindan bozuktur.

28 Emir Süleyman'ın adı kendisi için yazılan şïrlerde Mỉr Sülmān ve Mĩr Süleyman olduğu gibi, Mir Selmān olarak da harekelenmiştir, bkz., Kahire yazması yk. 15 a, beyit 3 ; yk. 22 b, beyit 5,10 ; yk. 26 a, beyit 12; krş., T. Kortantamer, Leben und Weltbild, s. 122. 
Emir Süleyman Rumeli'den Anadolu'ya geçip, Bursa'ya yürüdüğünde Mehmed Çelebi, Bursa'yı boşaltıp, Amasya'ya çekilmişti. Mehmed Celebi' nin Giyaseddin olan lakabi ${ }^{29}$, "Gıyās̄", "Giyās̄-1 dīn" ve benzeri biçimlerde hem Dâ'î'nin hem de Ahmedî'nin Mehmet Çelebi için yazdıkları şiirlerde görülmektedir $^{30}$. Bu bakımdan yukarıdaki kasidenin aşağıdaki 27 . beyitinde yer alan "el-ġ̀yās̄" kelimesi, asıl anlamının yanında gerçekten, bizim düșündüğümüz gibi, ayrıca bir de Mehmed Çelebi'ye telmih için kullanılmışsa, bu kaside de Dâ'î'nin Emir Süleyman'la birlikte Anadolu'da bulunduğu sürenin ürünü olabilir ${ }^{31}$. Dâ' î’nin beyitlerinde, Emir Süleyman'ın atı yıldırım gibidir, kılıcı düşmanın kanını döker ve zaman böyle bir sultanla övünür:

Atuñ bir yıldırımdur kim atar șeyțānı od birle 32 İder ${ }^{33}$ el-ğ̀yāṣ andan kaçarlar el-ḥızār andan

Ḳllıcuñ düşmanuñ ḳanın şu deñlü dökdi her yire Ki țāg u țāşile șaḥrā aḳıttı cūyibār andan …

Ne kutlu rūzigār ol kim bugün ol faḩr ider senden Zeht Sulțān ki faḩr eyler bugün uş rūzigār andan

Aynı kasidenin son bölümünde Dâê̂ bir sıkıntısını dile getiriyor: Aralıksız, Emir Süleyman'ı öven, ona dualar eden şiirler yazıp göndermektedir. Bir karşılık görmemiş olacak, şiirlerinin Emir Süleyman’a ulaşmadığını düşünür, ya da öyle düşünüyormuş gibi yapmak işine gelir. Temiz yürekle edilen duaların arşa bile eriştiğini aklına getirip, Emir Süleyman'a yol bulamayıșına şaşar. Emir Süleyman onun şiirlerini duysa, onu unutmayacaktır. Dâê daha sonra edep sınırlarını aşmış olabileceğini belirtip af dilerken, bağış bekler:

29 t. H. Uzunçarşıll, "Mehmed I", İA VII, s. 496-497.

30 T. Kortantamer, Leben und Weltbild, s. 190-192; Kahire yazması, yk. 7 b, beyit 4. Yalnız, Dâcî'nin Câmi'ü'n-nezâ'ir'deki kasidede Emir Süleyman'dan da Giyãs̆-1 dīn ved-dünyā diye söz ettiğini söylemek gerekir, bkz., 1. H. Ertaylan, Ahmed-i Dâĉ̂, Türkçe Divanı, Tıpkıbasım, s. 142, beyit 11 .

31 Yalnız, bunun böyle olduğunu kesinlikle ortaya koyan hiçbir delile sahip olmadığımızı hemen belirtmemiz gerekir.

32 Kahire yazması, yk. 13 a, beyit 15 ; yk. 13 b, beyit 1,4 .

33 "İder" yazmada açıkça harekelenmiş olmakla birlikte vezin ve anlam yönünden "eyidür" olmahdur. 


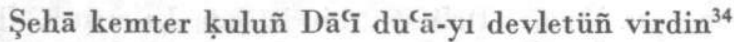
Düzer incū gibi naẓma işidüñ yek du bār andan

Șabā peykiyile medh ü ducālar gönderür her dem Meger hażretde yol bulmaz kim itmez reh-güzaār andan

Dữā ib̧lāsile 'arşa irer līkin ne hịkmetdür Şu 'ālī hażrete varmaz 'aceb bu āh ü zār andan

Ya-b̧od deryādur ol hażret ne kıymet gevhere andan Șadef aḩmaz gibi țaşra çekerse intiẓār andan

Velī luțf ıssıdur ol Şāh ișitse bendenüñ naẓmun 'İnāyet birle yād eyler unutmaz zīnhār andan

Eger şarț-1 edebden ḳul tecāvüz eyler ol 'afv it Gerek luṭf u 'ațā senden dữã vü iftihār andan

Bu beyitler Emir Süleyman'ın Dâ'̂̂’ye en azından bir süre ilgi göstermediğini ortaya koyuyorlar. Dâề ise, neyi nasıl anlatacağını bilen bir beceriklilikle ona sokulmaya çalışmaktadır. Benzeri bir durum Emir Süleyman için yazılmış bir başka kasideden alınan aşağıdaki beyitlerde de göze çarpıyor: Bugün, Yaratıcı'nın eseri (Emir Süleyman) "sa‘̄adet mațlaఢı"ndan doğmuştur. Güneş bile Şahlar Şahı Osmanoğlu Emir Süleyman'ın parıltısından aydınlanır. O, Allah'ın yer yüzündeki gölgesi olmuştur ${ }^{35}$. Kişiliğinin ve eli açıklığının benzeri yoktur. $O$ hilafet tahtına çıktığından beri ${ }^{36}$ yedi iklim onun ya-

34 Kahire yazması, yk. $13 \mathrm{~b}$, beyit $5-10$. Burada verilen ilk beyit Burdur yazmasinda da yer almaktadır Bkz., I. H. Ertaylan, Ahmed-i Dâcî (Tıpkıbasım), s. 82, beyit 2.

35 "Allah'm halifesi" ya da "Tanrı'nm yeryüzündeki gölgesi (zill Allāh fĩ'l-arż)" gibi sözler daha İslam'n erken çağlarında müminlerin halifeye göstermek zorunda olduklan itaati belirtmeye yaryyordu. Bunlarnn izleri Hadis edebiyatında da bulunuyor. "Tanrı'nn yeryüzündeki gölgesi" sözü sonraları, halifeler dışında, hükümdarlar tarafindan dünyevî hükümranhğı din açısından meşrulaştırmak için kullanılur oldu, bkz., Sir Thomas W. Arnold, The Caliphate, s. 50 ve öt,, 203-204; J. H. Kramers, "Sultan", İslam Ansiklopedisi, c. X, s. 24-25; C. H. Becker, "Barthold's Studien über Kalif und Sultan", Der İslam VI (1916), s. 350-412; Gustave E. von Grunebaum, Der Islam im Mittelalter, Zurich 1963, s. 24.

36 Moğollar 1258 yılında Abbasî Halifeliği'ne son verdikten sonra Islam ülkelerinde tahta geçmeyi başaran müslüman her hükümdarın, Allah hükümranlığı kendisine verdiğinden, Halife olduğu düşüncesi yaygınlaştı ve halifenin Kureyş'li olması şartı bir kenara burakaldı. Bu düşünceyi meşrulaştıran deliller de Kuran'da arandı, bulundu. Söz gelişi: III, 25; VI, 165; XXXVIII, 26. Osmanlı hükümdarları daha 14. yüzyılın ikinci yarısında, I. Selim'in Mısır'ı ele geçirmesinden önce, halife ünvanını kullanır olmuşlardı, bkz., T. W. Arnold, The Caliphate, s. 106, 107 ve öt.; T. W. Arnold, "Halife", Islam Ansiklopedisi, c. V, s. 151; Becker, "Barthold's Studien über Kalif und Sultan", Der İslam VI (1916), s. 351, 372 ve öt.; Şinasi Altundağ, "Selim I", Islam Ansiklopedisi, c. X, s. 423-434; krş., T. Kortantamer, Leben und Weltbild, s. 377-378. 
salarına boyun eğmektedir. Dâê̂ ise, bir köşede kalmıştır. İlim ve hünerin değerini bilen, hüdhüd gibi Süleyman'a karıncanın ${ }^{37}$ (kendisinin) durumunu iletecek ikinci bir Âsaf ${ }^{38}$ aramaktadır. Emir Süleyman herkese bağışlarda bulunmuş, herkesi giydirmiş ve doyurmuştur. Ortada kalan bir Dâề'dir ve kendisinin Emir Süleyman'ın eli açıklığından yararlanmasına kimin engel clduğunu bilememektedir. Emir Süleyman'a sığınmaktan başka çaresi de yoktur. O elinden tutmazsa, ziyan olacaktır; ama umutludur. Emir Süleyman'ın alıc olduğu değerli incileri (şiirleri) satan kişinin (kendisinin) mutlu olacağına inanir:

Bi-ḥamdi'llāh bugün ol șunc-1 șānic3

Sac̄āet mațláindan oldı țālic

...

Şehenşeh Mīr Selmān ibni 'Oşmān

Münevver țal'atından șems-i sāti ${ }^{\mathrm{c} 40}$

Çu ẓllu'llāhi fr̂̀l-arż oldı zāātı

Yüzinden nūr alur her gün mețālic

Anuñ zoātına yoḳ mișl ü müşābih

Anuñ cūdına yok şibh ü mużāric

...

Selāțīn-i cihān emrüñe münḳād

Şehenşehler ḳamu hükmüñe rācic

...

37 Süleyman Peygamber'le ilgili bir hikayede hüdhüd, Süleyman Peygamber'e Saba ülkesinden haber getirir ve Süleyman Peygamber'in mektubunu Saba Melikesi'ne götürür. Bir başka hikayede ise, Süleyman Peygamber karmealarm bulunduğu vadide karıncaların başını çağırır ve onunla görüşür; daha geniş bilgi için bkz., Ali Nihat Tarlan, Şeyhî, s. 262 ve öt.; krş., Heinrich Speyer, Die biblischen Erzählungen im Qoran, Darmstadt 1961 (tupkibasim), s. 373 ve öt., 390 ve öt. Ahmed-i Dâĉ bu motifleri burada, kendisine bir süredir ilgisiz kalan Emir Süleyman tarafından çağırılma isteğini dile getirmek için kullanıyor. Benzeri bir durumda, benzeri bir kullanı̧ı Ahmedî'de de buluyoruz:

Hüdhüd bigi çu peyk-i Sabā'sın sen iy șabã

Karnncanuñ sözini Süleymān'a 'arża ḳ̣l

Bkz., T. Kortantamer, Leben und Weltbild, s. 161.

38 Süleyman Peygamber'in veziri, bkz., A. J. Wensinck, "Āṣaf b. Barakhya", İslam Ansiklopedisi, c. I, s. 664 .

39 Kahire yazmasi, yk. 15 a, beyit 1, 3-5, 11; yk. 15 b, beyit 1; yk. 17 a, beyit 1-10.

40 Yazmada "sāti" yazılmışsa da "sāți" olması gerekir. 
Hulāfet tahıtına sen şāh olah

Yasag̉undan yedi iḳlīm hāşic

....

Şehā senden gerek tā kim bu ḳulda

Göresin neylemişdür șunc'-1 șānic

Benem 'anḳā-ṣıfat 'uzletde ḳalmış

Kanā'at künçinün ${ }^{41}$ gencine kānini

Kanı ol Âṣaf-ı sānī ki her dem

Ola Cilm ü hüner ḳadrine rāfíc

Süleymān'a ḳarınca vaṣf-ı ḥālin

Diye hüdhüd gibi hem ola şâfic

Güneşsin 'āleme hergün țogarsın

Kamu zerrāt olur şu leñde lāmic

Ki her dem hil'atüñden ni'metüñden

Ṭonandı tọoydı her 'uryān u cāmic

Benem ol zerreden kemter dahi kem

'Aceb ney ki benüm hakậumda mānic

Eger ḥālüm saña 'arz itmez isem

Kime 'arż eyleyem kim ola sāmic

'İnāyet gözi birle baḳmaz iseñ

Kalurven Ḥaḳ țanuḳdur şöyle zāyic

Çu sensin müşterī dürr-i yetīme

Zihī devlet anuñ kim oldı bāyic

Dâê̂ bir tercî-i bendde, gene içkiden ve Emir Süleyman'ın hem doğunun hem batının haracını alan, herkesin derdine deva olan, çılakları donatıp, açları doyuran bir hükümdar olduğundan, büyüklüğ̈̈nden, saltanatının heybetinden söz ettikten sonra, yukarıdaki örnekleri çok andıran bir biçimde durumundan yakını:

41 Metinde " $\varsigma$ " açıç̧a üç nokta ile yazalıdur. 
Gösterdi şīşe odile șu imtizācın ${ }^{42}$

Yacnĩ ki cãm içinde sücinüñ mizācını

Cevher ki cisme rūḥ olur ol rūḥa 'aḳl-1 kül

'Akluñ dimāg̀ içinde yaḳar ol sirācını

Sāḳtyi gör ki gösterür uş nãz u cevrile Nāzüklüginde hüsn ü melāḥat revācını

Bu zulme dād virmeye illā meger kim ol Şāhĩ kim aldı mag̉rib ü māşrıḳ ḩarācını

Virdi eline baḩt u sa⿳ādet inānını

Koydı başına devlet $\bar{u}$ iḳbāl tācını

Rūḥü'l-ḳudüs- șıfat ider ol derd-i dillere

Her bir nefesde her kişinüñ her 'ilācını ......

Cūduñ sehã vü ni'metile halḳ-1 'ālemüñ

Yalıncag̀ın țonatdı vü țoyurdı acını …..

Şāh-1 zemāne Mīr Süleymān-1 nīk-baht Dārende-i sacādet ü Dārā-yı tāc u taḩt ...

Şāhā senüñ bu salțanatuñ heybeti bugün

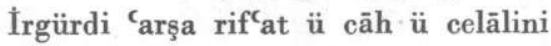

$$
\text { ... }
$$

$\mathrm{Dāc}^{-1}$ kuluñ revã mı göñülden karībiken Bī-cürm ü bĩ-günāh țapuñdan ba'ĩd ola

Müşțāḳ-ı hażzet ola dabı ol firāḳle Gözden iraḳ düşe vü göñülden ferīd ola

Ne șoḥbet-i șafã göre ne cām-1 mey içe Zühd ü riyāżetile ḳuruya ḳadìd ola

42 Kahire yazması, yk. 25 b, beyit 11-13; 26 a, beyit 6-8, 10, 12; yk. 26 b, beyit 7; yk. 27 a, beyit 7-13. Burada verilen ilk üç beyit ve son beyit Burdur yazmasında da yer ahyorlar, krş., t. H. Ertaylan, Ahmed-i Dâcî (Tupkıbasım), s. 49, beyit 8-10, s. 21, beyit 5 . 
AHMED-İ DẤ̂̂ ÍLE İLGILİ YENİ BÍLGÍLER

İşbu hevã țabt'atini köhne eyleye

İşbu hevesde gușșası her gün cedîd ola

Gelmişdür ol ümīze kim $^{43}$ dergāha yüz süre

Ḥāşā ki ol ḳapuñda senüñ nā-ümtž ola

Íblāṣı tọgru șıdḳı bütün bendedür saña

Ger rūzigār öküş geçe müddet medīd ola

Her dem du'ā-yı devletüñi ber-mezīd ider

Hakạdan diler ki devlet ü “ömrüñ mezĩd ola

Nergis redifli kasidesinde de Dâtî, içinde bulunduğu güçlüklerden yakınıp, Emir Süleyman'ın yardımını istiyor:

Dāci ol ḥażret-i 'ālīde senālar idicek ${ }^{44}$

Her gazel kim yazaram ben okur ezber nergis

Ney-şekerdür kalemüm medḥüñi taḥrir ideli

'Anber ü müşk midād oldı vü defter nergis

Hüsrevā ḥālüme bir kez naẓar it kim işidüb

Gonçe yırtar yaḳasın dabı esirger nergis

Ger ben ol lāle- șıfat göynügümi şerḥ ḳılam

Kuru gözden aḳıda çeşme-i kevșer nergis

Ne revā çarb kabag̉um șıya şīşem uvadub

Sag̀raḳın lā $\mathrm{T}$ ìde gonçe ḳadeḥin zer nergis

Ben ki āzādeyiken serv bigi bt-ber olam

Dahı tāc üstine düze ${ }^{45}$ ḳat ḳat cevher nergis

Kuurı sözile boş elden ne geliser likkin

Gözlerüm yaş țoludur (ur) nitekim ter nergis

43 "Kim" vezne göre "ki" olmahdır.

44 Kahire yazmas1, yk. 14 b, beyit 5-13.

45 Vezne göre "ḳat ḳat düze" olması gerekir. 
Bir Cināyet naẓarın ḳıl ki ser-efrāz ola serv Müflisiken zerile ola tuvānger nergis

Her ki nergis gibi göz dikdi bu cālt ḳapuya Gül gibi hoş güler ol nite ki nevber nergis

Anlaşılan Emir Süleyman'ın, Dâê̂'nin kapı yoldaşı Ahmedî'de gördüğümüz gibi, Dâê̂’den de yüz çevirdiği olmuş ve Dâê güç durumlara düşüp, Emir Süleyman'ın çevresine gene girmeye çalışmış ${ }^{46}$.

Buna karşılık, Dâê̂'nin pek çok şiiri, Emir Süleyman'ın onu çoğunlukla koruduğunu ve ona yakınlık gösterdiğini ortaya koyuyor. Söz gelişi, bir kasidede Emir Süleyman'ın çok yardımını, iyiliğini, bağışlarını gördüğünü, bunlara karşılık, şükran duygusunun binde biriyle yazdığı övgülerin defter, onu anlatan şiirlerin de divan doldurduğunu söyleyip, Emir Süleyman'1, Süleyman Peygamber'e, kendisini de Selman'a benzetiyor ${ }^{47}$ :

Ni'metüñ haḳḳumda çoḳdur kim ḳ̂lur şükrin anuñ ${ }^{48}$ 01 ḳadar inçām idüb ol deñlü iḥsān eyledi

Kim anuñ biñde birinüñ şükrini zikr itdi çun Medhüüni defter ḳulub vaṣfuñda ditvān eyledi

Çun seni himmet bile şehā ${ }^{49}$ Süleymān itdi Ḥaḳ Medḥ içün anı dahı 'aṣruñda Selmān eyledi

Dâ'î'nin başka bir kasidesinde Emir Süleyman'a yakınarak anlattıkları, okunur okunmaz akla Şeyhî'ye Harnâme'yi ${ }^{50}$, Fuzûlî'ye Şikayetnâme'yi ${ }^{51}$ yazdıran olayları getirmesi bakımından çok ilgi çekiyor. Emir Süleyman bir köyün vakıf gelirini Dâ'î’ye vermiştir. Kâzi'l-kuzât, onun bu geliri almasını

46 Krş., T. Kortantamer, Leben und Weltbild, s. 153-165.

47 Adı Cemâlü'd-din Muhammed b. Alâü'd-din Muhammed olan Selman-ı Sâvecî (ölümü 1376) için bkz., Tahsin Yazıcı, "Selman", IVA X, s. 458-461.

48 Kahire yazması, yk. 25 a, beyit 3-5.

49 Vezne göre "şāhā" yazılmalıdır.

50 Harnâme için bkz., F. K. Timurtaş, Şeyhî'nin Harnâme'si, Edebiyat Fakültesi Yayınlarından No. 1629 Türk Dili ve Edebiyatı Bölümü, Edebiyat Fakültesi Basımevi (İstanbul) 1971.

51 Şikayetnâme için bkz., Abdülkadir Karahan, "Fuzulînin Mektuplar”,, TDED, c. II (1948), s. 246-257. 
engeller ${ }^{52}$. Dâề öfkeli ve küskündür. Kendisine böyle davranan kişinin rüşvet aldığını, yetim malı yediğini belirtir. Kendisinin böyle şeyler yapmadığını, padişahın verdikleri ile yetindiğini eklemeyi de unutmaz. Kendisinin çok himmetli olduğunu, gene de korunmadığını söyler. Sonra haklı olduğuna inandığın sezdiren bir biçimde, söylemiş olabileceği yanlış ve yersiz sözler için af dileyip, kırgınlığını ve kızgınlığını göstererek, Tanrı'dan, sıkıntısız alabileceği bir ölümsüz dirlik ile bir tükenmez hazine ister:

Hü̈revā bir hoş hịkāyet 'arz ider Dāct ḳuluñ ${ }^{53}$ İşbu surruñ hịmetinde ney ki esbāb u cihāt

Tañrı'dan șāhịib-naẓarsın örtilü sır yoḳ saña Her kişi hālin bilürsin yatlu yā kimdür oñat

Bir 'ibäretden idersin bunca biñ keşf-i rumūz Bir ișāretden ḳılursın bunca hall-i müşkilāt

Vaḳf-1 kūyuñ hāạılātın vacde ḳılduñ bendene Muntaẓrven ol vefāya tā ilā yevmi'l-vefāt

Gerçi her mennā-1 hayr ol ḩayrı benden mencider Bu 'aceb sırdur ki niçün yir anı her Türk-i tāb

Bir Beg'üñ hayrın baña virmek revã görmez dahı̣ Her yetîmüñ māli birle 'iș ider kāāîil-ḳużāt ${ }^{c}$

Ger baña cām-1 meyile țán iderse Hak bilür Ol yidügi zehrdür ben içdügüm āb-1 hayāt

Şükür ${ }^{54}$ kim rişvet yimezven yā degül māl-ı yetīm Pādişāh hayrından ol bir sadaḳadur ${ }^{55}$ yā-ḩod zekāt

Himmetüm 'anḳā- șıfatdur ḳāf-1 cuzletdür yeri Konmag̉a bir yir bulunmaz uçmag̉a yoḳdur ḳanat

52 Fetret devrini izleyen yllarda bütün kadılann başı durumunda olan tek bir kazasker bulunmaktayd,, M. Akdağ, Türkiye'nin iktisadî ve içtimâ̂ tarihi, c. I, s. 399. Dâ'̂́’nnin burada şikayetçi olduğu kazaskerin kim olduğunu bilemiyoruz.

53 Kahire yazması, yk. 18 a, beyit 8-15; yk. 18 b, beyit 1-5.

54 "Şükr" olması gerekirken metinde "şükür" olarak harekelenmiştir.

55 "Sadḳa" olması gerekirken metinde "sadaḳa" olarak harekelenmiştir. 
Ādemīnüñ dünyada bir gūşesidür rāhatı

Yokssa her käfir umar yarın

Ger ḩațāyise sözüm estagifiru'llāha'l-'aẓim

Sözde istiğfār olursa 'afv olur çok seyyi'āt

Yã Îlāhī sen ḳanā'at gencini erzāni ḳ̂l

Bir muḳadder rıẓ̣içün bārī nedür bu turrehāt

Bir ölümsüz dirlikile bir dükenmez genc vir

Kim ne gaybet olsun anda ne gile ne mühmelāt

§ Gelibolulu Mnstafa Ali'ye göre Dâ'î, Germiyan'da kadılık etmiş ${ }^{57}$. Germiyan'ı bilmiyoruz, ama Dâ'î’nin kendisinin rüşvet yemediğini söylediği 15 . beyit, bizde, onun Emir Süleyman devrinde kadılık yapmış olabileceği izlenimini uyandırıyor; çünkü rüşvet yiyebilmesi ya da yememesi için herşeyden önce bu işleri yapabileceği bir memuriyeti olması gerekir. Ayrıca burada çatıştığı kişi en büyük kadıdır. Dâ'̂̂’nin olayı anlatırken, saygı çerçevesi içerisinde, korkusuzca davranışı da onun Emir Süleyman'ın yanında nasıl sağlam bir yeri olduğunu gösteriyor.

Dâ'̂̀’nin Emir Süleyman için yazdığı şiirlerin aşağı yukarı hepsinde içkili toplantılar ve şarap önemli bir yer tutuyorlar. Bu konuda Dâê̂ ile kapı yoldaşı Ahmedî'nin şiirleri arasında, ikisinin söyleyişleri başka başka da olsa, büyük benzerlikler göze şarpıyor ${ }^{58}$. Anlaşılan bunlar daha çok Emir Süleyman'ın isteklerine uygun, onun beğendiği biçimde yazılan şiirler. Bunlar bir bakıma Emir Süleyman'ın karakterini ve o sıralardaki ruh halini yansıtıyorlar. Çünkü Dâê̂'nin olsun, Ahmedî'nin olsun Mehmed Çelebi için yazdıkları şiirler değişik bir hava taşıyorlar ${ }^{59}$.

Diş görünüşe göre Emir Süleyman saltanat sürüyor, güçlü; gene de çatışmalardan duyulan bir huzursuzluk var. Buna karşılık içkide kaygılardan kurtulma yolu araniyor:

56 "Paradiss ü balāt" olabilir.

57 i. H. Ertaylan, Ahmed-i Dâĉ, s. 12.

58 Ahmedî'nin şiirleri için bkz., T. Kortantamer, Leben und Weltbild, s. 133-135, 141, 146-149, 157-158, 172-173.

59 Ahmedî’nin Mehmed Çelebi'ye yazdığı şïrler için bkz., T. Kortantamer, Leben und Weltbild, s. 174 ve öt. 
İçelüm ol sāḳi-yi maḥbūb elinden kim ola ${ }^{60}$

Sireti 'Îsā nefeslü șūreti Yūsuf-ṣıfat

Rūzigāruñ giușasasından cānumuz bulsun ferāḥ

Nevbahāruñ müjdesinden çun cihān dutdı sebāt

Vaktümüz gavgā elinden bir nefes bulsun amān

'Aḳlumuz sevdā yöninden bir nefes bulsun necāt

Hāșșa hengām-1 tarabdur mevsim-i nevrūz u cid

Bād-1 meymūn-1 mübārek bir șeh-i ferhunde zāāt

Gün Emir Süleyman'ındır. O, saltanat sürmektedir. Devir rahat, ihsan, adalet, içki ve eğlence devridir. Korkmamak gerekir:

Nicmet ü rāḥat demidür salțanat devrānıdur ${ }^{61}$

'İ̧ u Cişaret nevbetidür 'adl ü iḥsān devridür

Hamdü li'llah kim senüñdür devrile devrān bugün

İç senüñ devrüñdür ol șanma ki devrān devridür

'İşret ü żevk u ṣafānuñ vaḳtidür $D \bar{a} \bar{c}^{\mathrm{i}}$ bugün

Saġarı țoldur içelüm korḳma kim Ḩān devridür

İçki yüzünden yapılan kınamalara aldırmamalıdır. İçki Emir Süleyman'ın aklını dimağını tazeler ${ }^{62}$ :

Hüsrevā şarț-1 edebden ger tecāvüz eylerem ${ }^{63}$

Bir lațife eydeyim kim 'aḳl anı yāver ḳılur

Zãhid-i huşkuñ sözin ḳo raṭb u yābis söylesün

Sen iç ol cāmı kim ol caḳluñ dimāginn ter ḳılur

Hoş müferriḥdür bu sözler bāde-i aḥmer gibi

Lācerem tefrị̣ ḳalbi bādeyi aḥmer ḳlur

60 Kahire yazması, yk. 17 b, beyit 5-8. Burada verilen ilk iki beyit Burdur yazmasinda da bulunmaktadır.

61 Kahire yazması, yk, 23 a, beyit 6-8.

62 Ahmedî de Emir Süleyman için yazdığı bir şiirde:

Nice kim çoh içerise caḳlı kāmilter olur

Bilmezem şekker mi içer ya āb-1 ḥayvān yā gülāb

diyor. Ahmedî aynca Tervîhü'l-ervâh'da da Emir Süleyman'ı benzeri sözlerle över, bkz., T. Kortantamer, Leben und Weltbild, s. 172. Ahmedî olsun, Dâcî olsun bu, içkinin akh tazelemesi motifini divanlarında yalnız Emir Süleyman için kullanıorlar. 
Illkbaharnn değerini bilip, içmeyen suçludur. Zemheri ona ocak başında oturma cezası verir. Isınmak için sıcak şarap içmelidir:

Sen dabı evde otur altun sikek düz zìra kim ${ }^{64}$

Ḥak tacālā ḳ̣ş güni odı gülistān eyledi

Pubte iç germ ol sovukdur ham olub äh-1 sered

Yigrek oldur kim anı hikmetde Yūnān eyledi

Issı otlar yi sovuk içme (vü) perhīz it saḳın

Ol ṣudan iç kim içinde odı penhān eyledi

Her ki gül vaḳtinde şekker nuḳl idüb cām içmedi

Zemherīr uş zehrini ol cürme tāvān eyledi

Dün sögütler gölgesinüñ ḳadrini kim bilmedi

Lācerem ocak yaḳasın aña zindān eyledi

Senenin en uzun gecesi de içerek geçirilecek bir gecedir:

Sāḳiyā bu gicedür çün şeb-i yeldā gicesi ${ }^{65}$

'İşret ü 'iş u țarab zoveṿ u temāşā gicesi

Getür ol bādiyeden bādeyi șāfī içelüm

Bäri ṣäfĩ dilile cãm-1 muṣaffā gicesi

Muṭrib ü hūb-nefes birle sebük-rūḥ̣-1 nedīm ${ }^{66}$

Bāde ḥāzur ola vü nuḳl müheyyā gicesi

Mutâyebât, bugüne kadar sanıldığı gibi, Dâề'nin ayn bir eseri olmayıp, divandan seçilmiş, daha çok, şarap, şarap meclisi ve eğlence ile ilgili şiirlerin bir araya toplanmasıyla ortaya çıkmıştır ${ }^{67}$. Mutâyebât'ı oluşturan on altı

63 Kahire yazması, yk. 22 a, beyit 12-14.

64 Kahire yazması, yk. 23 b, beyit 14-15; yk. 24 a beyit 1, 8-9.

65 Kahire yazması, yk. $20 \mathrm{~b}$, beyït 13-15. Bu şïr Burdur yazmasında da bulunmaktadrr. Yalnız, şïrin Emir Süleyman için yazıldığını gösteren Kahire yazmasındaki iki beyit (şiirin 21. ve 22. beyitleri) Burdur yazmasında yer almadığından, Dâç’’nin bu şïiri kimin için yazdığı bilinmiyordu. Bkz., İ. H. Ertaylan, Ahmed-i Dâc, s. 71, Türkçe Divanı (Tıpkabasım, s. 21-23.

66 Metinde "muțrib ü hūb-nefes" ve "sebük rūḥ-1 nedīm" olarak harekelidir.

67 Durumu aydınlatan kısa bir yazımızın Türkoloji Dergisinin bu sayısında yayımlandı. 
şiirin on ikisi, Kahire yazmasımın açıkça gösterdiği gibi, divanda yer almaktadır. Mutâyebât'da olup, Kahire yazmasında bulunmayan dört şiirden birinde adı geçen Mihaliç, Bursa yakınlarındaki tanınmış Mihaliç (Karacabey) ise, bu şiirlerin en azından bir ikisi, belki de hepsi, Emir Süleyman'ın Anadolu'da bulunduğu 1405-1409 yılları arasında yazılmış olabilir. Burdur yazmasında bulunmayan aşağıdaki kıta da büyük bir ihtimalle bu devrenin ürünüdür.

Kış gelmek üzeredir. Dâê̂, Bursa'ya gidip, hazırlık yapmak ister:

İy sa ${ }^{c}$ ādet $m a^{c}$ deni Şehenşeh-i ${ }^{68}$ mālik-rikāāb ${ }^{69}$

Her seḥer vaḳti melāyikden saña alḳış gelür

Dā'i'ye destūr vir kim Bursa'ya varam daḩı

Kış yarag̉ın eyleyem şimdi kim elden iş gelür

Zemherïr oḳı güneş ḳalḳanını deldi geçer

Pes çukal geymek gerek zïra ḳlıc tek ḳış gelür

Emir Süleyman için yazılan şiirlerde en azından içki ve eğlence kadar ağır basan bir nokta da, yukarıda sık sık görüldüğü gibi, taht kavgasıdır ${ }^{70}$. Dâê̂ bu konuda da duruma göre, koruyucusunun beklediği, duymak istediği sözlerle olayları yansıtır.

Tanrı onun adını Emir Süleyman koyup, onu bugün sultan yaparak, o melek yaradılışhyı meliksiz kalan mülk için insan kılığına sokmuş ve uçmağından bir il verip, adına Osmanlı ülkesi demiştir. Devlet Emir Süleyman'a Tanrı'nın hediyesidir. Onun devletinin güneşi Tanrı gölgesidir:

Zīra kim Tañrı tacāā raḥmeti birle bugün ${ }^{71}$

Hulḳa halḳun peykini 'ālemde sulțān eyledi

Zātını baht u sacādet birle uş te'yid ĩdüb

Adını levḥ-i ezelde Mĩr Süleymān eyledi

Tañrınuñ hịkmetlerin gör bir meliksüz mülk içün

Ol melek sīretlüyi şūretde insān (eyledi)

\footnotetext{
68 Vezin dolayısıyle "şâhenşeh" olması gerekirken metinde "şehenşeh" olarak harekelenmiştir.

69 Kahire yazması, yk. 120 b, beyit 1-3

70 Dâç'nin Emir Süleyman için yazdığı şürler bu açıdan da Ahmedî’nin şürleriyle büyük bir uyum içindedir,

71 Kahire yazması, yk. 24 a, beyit 15; yk. 24 b, beyit 1, 3-4, 9-10.
} 
Ucmag̀ından dünyāya bir il viribidi meger Emn ü rāḥat birle adın milk-i 'Oșmān eyledi $\ldots$

Hüsrevā Ḥaḳ'dan 'aṭādur baḩtile devlet saña Salțanat menşūrına aduñı 'unvān eyledi

Devletüñ hưrșīdidür 'ālemde Tañrı gölgesi Zātuñı anda penāh-1 ehl-i ìmān eyledi

Tanrı onu özene bezene yaratmış, âlemin serveri yapmış, başına saltanat tacını giydirip, memleket tahtına oturtarak Mir Süleyman adını vermiş ve zamanın Süleyman'ı etmiștir:

Șānic-i zü̈ll-men kim ol bir kațreden güher ${ }^{72}$ ḳlur $^{73}$

Ţal'atın şems ü cemālin müşterī-manẓar ḳılur

Kāyinātuñ 'unșurından bir güher terkỉb ider Bahtile devlet virür hem 'ãleme server ḳılur

Salțanat tācın urur başına biñ ičaār ile Memleket tahtında anı Hüsrev ü Sencer ḳlur

Șūret-i ma'nī içinde zāātını maḥcūb ider Ḥüsn ü bulḳ u luṭfile dildār ider dilber ḳlur

Hem sacādet ni'metini aña erzānī țutar Hem Müceyyed-yed bağışlar hem Muẓaffer-fer ḳılur

Mīr Sülmān ad virür eyler Süleymān-1 rūzigār ${ }^{74}$ Şükr aña kim rạ̣metinden bu cinãyetler ḳlur

O, cihan şahıdır. Fetih ve zafer onundur. Her yandan haraç alır. Gaziler onun buyruğunda ülkeler fethederler. Halk sarayını bir Kabe gibi tavaf eder. Düşmanının ömrü kısalmıştır. Onu hemen yok etmese de birşey olmaz. $O$ veliahddır:

72 Metinde "güher" olarak harekelenmiştir.

73 Kahire yazması, yk. 21 b, beyit 9-14.

74 "Süleymān-rūzigār" olması gerekirken metinde "Süleymān-1 rūzigār" olarak harekelenmiştir. 
Şāh-1 'ālem Mĩr Sülmān kim anuñ zihnnindedür ${ }^{75}$ Levḥ-i maḥfūz üzreki mecmūc-1 naḳş-1 kāyināt .

Āyet-i innā fetaḥnā çun senüñ şānuñdadur Fetḥ ü nuṣret '⿳āyetidür rāyetüñde beyyināt

Devletüñde her țarafdan cem olur her gün barāc Himmetüñde her diyārı feth ider her gün giuzāt

Dergehüñ bir Kabedür kim halk ider her dem țavāf Leşkerüñde her zemān meveūddur hāec u gazāt $\cdots$

Ḥāsidüñ naḳdi dükendi nola mühlet vir aña

Düşmanuñ 'ömri ḳısaldı gam degül ipin uzat

Çun veliyyu'l-‘ahd sensin pes kerāmetdür saña

Tañrıdan fażl u 'ināyet Muṣțāfā'dan mu'cizāt

Mehmed Çelebi, Bursa ile birlikte Ankara da dahil olmak üzere Anadolu' nun batısını eline geçirmiş olan Emir Süleyman'dan kurtulmak için Karaman, Germiyan ve İsfendiyar Beylikleri ile anlaşarak, kardeşi Musa'yı, Emir Süleyman'ın arkasını dayadığı Rumeli'de, kendisine bağlı kalıp, Emir Süleyman'a karşı ayaklanmak üzere, yola çıkarmıştı. Emir Süleyman'ın bir süredir hükümdarlığı elinde bulundurduğundan ve düşmanın çokluğundan söz eden aşağıdaki beyitler o günlerin ürünü olabilir:

Hālıḳ-1 żü'l-men ezelde ihtiyār itmiş seni ${ }^{76}$

Țālic-i hoş-fäl-i bưrrem baḩtiyār itmiş seni

Devletüñden fahr ider çoḳ rūzigār oldı cihān

Lãcerem devletde fahrr-1 rūzigār itmiş seni

Himmetüñ șābit-ḳademdür Ḥaḳ yolında ṭog̉rısın

İşbu manșıbda anuñȩun pāyidār itmiş seni

Şāh-1 ‘ālem Mīr Sülmān-1 Süleymān-rūzigār

Bu kamu şehler içinde șehriyār itmiş seni

75 Kahire yazması, yk. 17 b, beyit 9; yk. 18 a, beyit 1-3, 6-7.

76 Kahire yazması, yk. 27 b, beyit $2-7,12-13$; yk. 28 a, beyit $1,9$. 
Babtile hemden ḳlupdur ${ }^{77}$ nuṣretile hem-nişt̄n Fetḥile yoldaş idüb iḳbāle yār itmiş seni

Dost ger yardım kulur yā mekr ider düşman ne gàm Çunki manșūr u mựaffer Kirdigār itmiş seni ...

Düşmanuñ ḳumdan çogise başına țoprak anuñ Ḥaḳ tacālã yir yüzinde ber-ḳarār itmiş seni

Gerçi kim a'dā-yı sebük yil gibi çok yiltenür Kăf țag̀ı tek halīm ü bürd ü bār itmiş seni

Her kim ol senden naẓar bulmadı olmaz mucteber Zĩra bu 'aṣr içre șāḥib-ítibār itmiş seni

Müddeç dillü șıfat ger mekr idüb ḳuyruḳ yalar Avlağ̀l anı ki ${ }^{78}$ şīr-i şikār itmiş seni

Halk eger birbirne sig̀nunursa sen Haḳḳa sıġ̀n

Düşmanuñ ger șad olursa șad hezār itmiş seni

Musa Çelebi Rumeli'de başarı kazanınca, Emir Süleyman'ın kendisine güç veren bu bölgeyi kurtarmak için Edirne'ye dönmekten başka çıar yolu kalmamıştı. Emir Süleyman'la birlikte mi bilmiyoruz, ama Dâ'î'nin de Emir Süleyman Anadolu'dan ayrıldıktan sonra Rumeli'ye gittiğini gösterir işaretler az değil. Bunlardan biri, Dâê̂'nin Emir Süleyman'ın ardından yazdığı güzel mersiyedir. Bu mersiyede Dâê, aşağıda görüleceği üzere Mehmed Çelebi'nin ardınan yazdığı mersiyede onun yerini alacak olan Şehzade Murad' dan söz edişi gibi, ya da Ahmedî'nin Emir Süleyman mersiyesinde ${ }^{79}$ ve Mehmed Çelebi için yazıp, Emir Süleyman'ın ölümünden söz ettiği bir başka şiirinde $^{80}$ yaptığı gibi, Emir Süleyman'ın yerini alacak kişinin adını vermiyor. Bu onun, Emir Süleyman'ın ölümünü duyduğunda kimseye sığınmamıs durumda olmadığı - Anadolu'da olsa, büyük bir ihtimalle M. Çelebi'nin ya-

77 Metinde "kılupdux" olarak yazilmıştır.

78 Mısram vezni düşüktür, "Avlag̉ıl anı ki Ḥak şĩr-i şikār itmiş seni”" olursa vezin düzeliyor.

79 Bkz., T. Kortantamer, Leben und Weltbild, s. 193-198.

80 Ahmedî'nin şimdiye kadar dikkati çekmemiş olan bu şiiri için bkz., T. Kortantamer, Leben und Weltbild, s. 190-192. 
nında bulunurdu - izlenimini uyandırıyor. Aynca o, bu mersiyede, Ahmedî’ nin aksine, olayları uzaktan duyan bir insana benzemiyor:

Șarardı heb ${ }^{81}$ çiçekler soldı güller ${ }^{82}$

Ḳamu bülbüller uş efḡāna geldi

Yaḳıldı lāle vü gözümde nergis

Hazān yili meger bustāne geldi

Kaulak işitmedi göz görmedi hīc

Anı kim hayf ol sulțāna geldi

Cihānda gelmedi hīe pādişāha

Bu hạalet kim Emīr Sülmān'a geldi

Çun ol Ḥaḳ raḥmetine vāṣıl oldı

Beşāret cennet-i rıżvāna geldi

Anuñ rūḥın görüb didi melāyik

Bu cennet tāvusı cevlāna geldi

Dirīgā ḳanı ol devletlü Sulțān

Cihānda adı kaldı Mīr Sülmān

Hudāyā her nefes biñ āh u feryād

Baña bu zulm elinden dād vir dād

.....

Kaanı ol pādişāh-1 nev-cuvān-baḩt

Sacādet gülșeninde serv-i āzād

Kahire yazmasında Dâê̂’nin Musa Çelebi için yazdığı bir kasidenin yer alışı da bu bakımdan anlam taşıyor. Bu kaside, Dâê̂’nin Musa Çelebi ile ilişkisini ortaya çıkardığı gibi, Dâ'î'nin, Emir Süleyman öldükten sonra Edirne' de kalıp, Musa Çelebi’ye katılmış olduğu düşüncesine yol açıyor.

Bu arada, Musa Çelebi, Emir Süleyman Anadolu'ya gelmeden önce babasının cenazesini Bursa'ya getirdiğinde, çok kısa bir süre için orada hükümdar-

81 Metinde "heb" olarak yazilmıştur.

82 Kahire yazması, yk, 34 b, beyit 11-13; yk. 35 a, beyit 1-5, 10. 
lığını açıklamış olduğundan, bu övgünün o zaman yazılmış olabileceği ileri sürülebilir. Ancak Dâê, Mehmed Celebi'nin Musa Çelebi'yi ortadan kaldırdığı 1413 yılında Farsça divanını Mehmed Çelebi'nin vezirâzamı Amasyalı Hacı Hayreddin Halil Paşa'ya ${ }^{83}$ sunduğuna göre, o yıllarda çok büyük bir ihtimalle Rumeli'dedir ve Emir Süleyman'ın ölümünden sonra Musa Çelebi'ye, onun ardından da Mehmed Çelebi'ye katılmıştır.

Dâ'̂̂’nin Musa Çelebi'ye övgüsünde de taht kavgasının izlerini buluyoruz: Tanrı, Musa Celebi'yi halkın koruyucusu yapmıştır. Din, şeriat, ilim, irfan, zühd, takva ondan destek bulmuşlardır. Kılıeı fitneyi durdurur, düşmanları ondan korkarlar. Yedi iklimde hükmü geçer. Saltanat ve devlet ona mirasdır.

Saġişsuz hamdile şükr ol yaratğan Ḥaḳ ta'ālāya ${ }^{84}$ Ki ḩalḳ üstine raḥmetden bıraḳdı uş Beg'i sāye

Ne sãye sãye-i Yezdān ki ḩurşīd-i sacādetdür Anuñ nūrı bile revnāḳ īrişdi dīn ü dünyāya

Şehinşeh Mĩr Mūsĩ kim yed-i beyżāsıdur mưciz Anuñ fethīidurur şāhid yed-i kudretde beyżāya

Anuñ devletlü dīzārı tecellī nūrıdur Ḥaḳka Zihī devletlü eān ol kim irişdi bu tecellāya

Şehā sen bir melek-sīret meliksin kim mülke ${ }^{85}$ senden İrişür hil'at ü ni'met ḳamu yohsulile baya

Saña Haḳdan 'atādur bu 'ināyet fetḥile nuṣret Seni tercīḥ ider devlet bugün Cimşīd ü Därā'ya

Senüñ 'adlüñ bile muḥkem esāsı Dìn-i İslāmuñ Senüñ ḥükmüñ dutar sāāit binā-yı şer ${ }^{c}$ ü fetvāya

83 1. H. Ertaylan, Hacı Hayreddin Halil Paşa'nın kimliğini bulmakta güçlükle karşılaştığı için onun Osmancıkh İmamzade Halil Paşa olduğunu sanmıştı, bkz., t. H. Ertaylan, Ahmed-i Dâci, s. 23-24. Mehmed Çelebi, Musa Çelebi'yi yenip, fetret devrine son verdiği surada Amasyah Hacı Hayreddin Halil Paşa vezirâzam bulunmaktaydı, bkz., M. Akdağ, Türkiye'nin iktisadî ve içtimaî tarihi, s. 393-394. Bu durumda açıça görüldüğü üzere Dâcî, Farsça divanını Osmancıkl Imamzade Halil Paşa'ya değil, Amasyah Hacı Hayreddin Halil Paşa'ya sunmuş olmahdır. 84 Kahire yazması, yk. 28 a, beyit 12-13; yk. 28 b. beyit 1-4, 10-12; yk. 29 a, beyit 3-5. 85 Vezne göre "mülke kim" olmahdır. 
Senüñ 'ilmüñdurur hāfız revāc-ı 'ilm ü cirfāna Senüñ nehyüñdurur nāṣır șalāh $u$ zühd ü taḳvāya

Senüñ ḳahruñ ḳılur Şehă $\bar{a}^{86}$ zemāne fitnesin sākin Senüñ luṭfuñ bile beñzer cihān firdevs-i a $9 a \bar{y} a$ $\ldots$

Siyāset yarlığın Şeha ${ }^{87}$ yürütdüñ yidi iḳlīme Kim uş āvāzesi yirden irişdi çarb-ı minnāya

İşidüb aduñı ḳorḳar ṣıdar ödi meḩāfetten Huṣūṣā ḩışmile bir kez naẓar ḳ̂lursañ acdāya

Sac̄āet salțanat devlet senüñ mevrūs̄-1 mülküñdür Ḳlıcuñ hü̈ccet-i kātıc yiter bu șıdḳ-ı dacvāya

Dâề'nin ne zaman yazdığı bilinmeyen bazı şiirlerinde onun Rumeli'de bulunmuş olduğu açıkça görülüyor:

\section{La -i lebüñe irmez elüm pes 'aceb degül ${ }^{88}$}

Ki Rūm ilinde la $1-i$ Bedehşān 'azīz olur

Dã`i'nüñ naẓmı bile bād-1 șabā $\bar{b}^{89}$

Rūm ilinden iltür Erzincān'a cān

Dâê, Mehmed Çelebi'ye gerçekten, bizim düşündüğümüz gibi, Edirne'de Musa Çelebi'nin ölümünden sonra katıldı ise, yalnız Kahire yazmasında bulunan kasidelerin birinden alınan aşağıdaki beyitler Mehmed Çelebi'nin Edirne'ye girişinin ardından yazılmış olmalıdır.

Mehmed Çelebi mutluluk bayrağını getirmiştir. Saltanatı elde eden odur. Tanrı ona boyun eymeyi zorunlu klmıştır. 0 , yurdun yapısını, dinin temelini, şeriatın kurallarını sağlamlaştırmıştır ${ }^{90}$ :

86 Vezin dolayısıyla "Şāhā" olması gerekirken "Şehâ" olarak yazılmıştır.

97 Vezin dolayısıyla "Şāhā" olması gerekirken "Şehā" olarak yazılmıştır.

87 Vezin dolayısıyla "Şāhā" olması gerekirken "Şehā" olarak yaz:lmıştır.

88 Kahire yazmasi, yk. 71 b, beyit 2.

89 Kahire yazması, yk. 103 a, beyit 9 .

90 İ. H. Ertaylan'm yayımladığı Burdur yazmasının tıpkıbasımında da bulunan Mehmed Çelebi için yazılmış iki ayrı kasidede buna benzer bir hava var. Bḳz., 1. H. Ertaylan, Ahmed-i Dâc, Türkçe Divanı, s. 13-19; krş., Kahire yazması yk. 7 a, beyit 7-13; yk. 7 b beyit 1-14; yk. 8 a, beyit 1-12 ve yk. 8 a, beyit 1-3; yk. 8 b, beyit 1-15; yk. 9 a, beyit 1-15; yk. 9 b, beyit $1-14$; yk. 10 a, beyit $1-9$. 
Şāhī kim ol getürdi sacādet livāsını ${ }^{91}$

‘Ālemde 'adlile Calem itdi hudāsını

Ol kim felekde rif'atini vașf ider melek Ger 'arż iderse salțanatı kibriyāsını

Ol kim ḳuşandı biline cür'et ḳuşag̉ını Ol kim țonandı eynine devlet ḳabāsını

Ol kim hitāb-1 izzetile kullarına Hạ Farż eyledi ițā'atile iḳtidāsını

Sulțān Muḥammed kim anuñ ferr ü devleti Kạṣr-1 müşeyyed eyledi milküũ bināsını

Kaānūn u 'adlile bugün ol muḥkem eyledi Şercüñ ḳavācidin dahı dīnüñ esāsını

Gene yalnız Kahire yazmasında bulunan bir başka kasidede ise, Dâê, saltanat kavgasında ortadan kalkan şehzadelerden geride kalanlar için araya girip, onların korunmasını ister. Bu şiirde Mehmed Çelebi'nin adı açıkça geçmiyorsa da, kılıç, karışıklık çıkarmağa yeltenen düşmanları yok ettikten sonra, Tanrının, kullarına iyilik olsun diye seçtiği, Dâê̂’nin kendisine "Gıyās̨-1 dīn" diye seslendiği kişi Mehmed Celebi'den başka kimse olamaz:

İạhār-1 raḥmet itmegiçün ḳullarına Hak $\mathbf{H}^{92}$

Halkẹ-1 cihān içinde seni ḳılmış iḩtiyār

Fitne odına yeltenen ol düşmanuñı gör

Kim bुākisār idübdür anı tīg̀-1 ābudār ${ }^{93}$

$\cdots$

Şehzādeler ki raḥmet-i Ḥaḳka ulaşdılar

Bādā bekā-yı devlet-i sulțān-ı kāmukār ${ }^{94}$

Yarın şefā'at itmekiçün pīşrev olup

C̈mrile devleti saña ḳodılar yādigār

91 Kahire yazması, yk. 6 a, beyit $6-8$; yk. 6 b, beyit 1-3.

92 Kahire yazması, yk. 34 a, beyit 4-5, 8-10, 12-13.

93 Kelime "āb-dār" olması gerekirken metinde "ābudār" olarak harekelenmiştir.

94 "Kām-kār" metinde "kāmukãr" olarak harekelenmiştir. 
laşmış. Bu şiirde artık, Mehmed Çelebi'nin kardeşleriyle yaptığı taht kavgalarının izleri kalmamıştır. Mehmed Çelebi düşmanlarını bağışlayan, çeşitli milletlere ve boylara hakim bir sultandır. Dâcî onbeş yıldır birlikte olduğu, çok sevdiği, herkesten sakladığı bir cevheri ${ }^{102}$ Mehmed Celebi’ye sunmaktan söz eder. Karşılık olarak bağış bekler. Beş yıldır dolaşıp, onun kapısına umutla gelmiştir:

'Afvi gör kim şunuñ gibi hașmi ${ }^{103}$

Kim getürdüñ ele vü āḩir-i kār

Şevketin eylemişiken maḳhūr

Taḩı olmuşiken çu tahta-i dār

Girü bāc u kemer virüb hil'at

Server eyledü ñ oldı ol serdār

…

Tīg̀-1 Sulțān Maḥammed-i Gāzī

Züül-fiḳār ola ber ser-i eşrār

....

Kapuña yüz sürer şeh-i maşrı̣

Ḥükmüñe ḳul durur Şeh-i Bulgār

Rūm u Rūs u Fireng tā mag̉rib

Getürürler harācuñı nāçār

Türkmān dilküdür sen aṣlanile

Ne it ola ki dem ura Tātār

....

İy Şehenşāh işit ducādan soñ

Bendenüñ bir garīb ḳıșșası var

Şāh içün kemīne bir cevher

Getürübdür lațif ü key şehvār

Cevher-i ābudār-1 ${ }^{104}$ nūrānī

Emles ü hoş ḳad ü tamām cayār

102 Dâc'r'nin bununla kimi ya da neyi kasdettiği anlaşılmıyor.

103 Kahire yazması, yk. 30 b, beyit 3-5, 10; yk. 31 a, beyit 1-3, 6-14; yk. 31b, beyit 1-15 104 "Āb-dār" metinde "ābudār" olarak harekelenmiştir. 
Belkim $^{105}$ ol cevherïñ 'ayārından

Hoiredür dĩde-i ulu'l-abṣār

Kān evi şu lesi birle rūşen

Cān gözi 'aksiyile pür envār

Vardurur bir safā ki zaātında

Giderür tīre-dārın ol jengār

Dil-rübādur çu naḳş-1 șūret-i çīn

Cān-fizādur çu zọevḳ-i șoḥbet-i yār

Anı her kim ki cān içinde dutar

Cānına irmeye belā-yı b̧umār

Tã göñül bag̉ladum maḥabbetine

Fārig̉ olmışam ez meşaḳkạat-i kār

Şimdi onbiş yıl oldı kim ikimüz Yoldaşuz bì-ḥicāb u bī-aġyār

Ben aña 'āşık ol baña ma'ş̄ụ Ol baña iş ${ }^{106}$ ü ben aña gam-ḩār

Ol iki yüz on altı kur'ațdur

Kizıl altun behāsıdur har-vār

Tāc-ı Sulțānile şeref bulıcak

Ḳımetine bilinmeye miḳdār

Ger kimsene diye ki ben gördüm

Bir anuñ misli bende cevher var

Eydüñ aña getürsün ol misli

Tā idem bunı anuñ üzre nis̄ār

Belki ḳan içre bir aña beñdeş

Hic yaratmadı Hālı̣̣-ı cabbār

105 Kelime metinde "belkim" olarak harekelenmiştir. 106 Metinde "iş" olarak harekelenmiştir. 
Niçe zālimlerüñ elinden anı

Kaçirup ḳurtarub ${ }^{107}$ görüb āzār

Cānum içinde saḳladum anı ben

Tã ki buldum bugün aña bāzār

Hānümānum bu yolda gitmişdür

Bilür anı şu 'ālimü'l-esrār

Biş yıl oldı ki sa'y idüb ḳapuña

Uş irişdüm gezüb bilād u diyār

Kapuña gelmişem ümīzile ben

Nā-ümíz itmegil beni zinhār

Şāh medhile olmışam márūf

Tā ki şeh 'adlin eyledi iạhār

Pādişāhuñ 'ațā vü cūdından

Eylemişem tevaḳḳuc-i bisyār

Hil'at-i hāș u bir eyü bedevī

Kim ola ḳor eyerlü hoş-rehvār

Dâề'nin Mehmed Çelebi'nin çevresinden beş yll gibi uzun bir süre neden ayrıldığın bilemiyoruz. İster bu süre içinde olsun, ister daha önceleri, şiirleri, onun değişik yerlerde bulunduğunu gösteriyor. Yukarıda görülen Bursa, Edirne, Mihaliȩ, Dimetoka ve Erzincan'dan başka, Bergama ${ }^{108}$ ve Akçakoyunlu ${ }^{109}$ isimleri ile de karşılaşıyoruz.

Dâề'nin Mehmed Çelebi için yazdığı mersiye ve II. Murad'ı hükümdar olarak öven üç şiiri, bugüne kadar kesin olarak çözümlenememiş bulunan kendi ölümü konusuna büyük bir açıklık getiriyorlar. Kaynaklardaki bilgiler tutarsız olduğundan ve Karaca Bey'in teşvik ile II. Murad adına Farsça'dan çevrilen Tezkiretü'l-evliyâ'nın Dâ'î'nin eseri olup olmadığı kesinlikle bilinme-

107 Metinde "ḳaçurup kurtarub" olarak yazılmıştır.

108 Kahire yazması, yk. 74 a, beyit 4 ; 1 . H. Ertaylan, Ahmed-i Dấ, Türkçe Divanı, Tıpkıbasim, s. $108-109,10$.

109 Kahire yazması, yk. $57 \mathrm{~b}$, beyit 8 . 
diği için bu konu karanlıkta kalıyordu ${ }^{110}$. Sözü edilen şiirler yardımıyla artık, Ahmed-i Dâ'î'nin en azından II. Murad'in saltanatının ilk yıllarında ihtiyar bir şair olarak yaşamakta bulunduğunu kesinlikle biliyoruz. Böylece Tezkiretü'l-evliyâ konusundaki tereddütler de büyük ölçüde gideriliyor.

Dâê, mersiyede Mehmed Çelebi'nin ölümünden duyduğu üzüntüyü dile getiriyor ve onun genç yaşta ölümünden yakınıyor. Şehzade Murad'in onun yerini aldığını bildirip, yeni hükümdara bütün devlet erkanını yerli yerinde bırakması öğüdünü veriyor:

Hicrān içinde yaḳdı beni işbu gam ḳanı111

Bir mürğ-i nevha-ger kim ide họs nag̉am ḳanı

Bag̀rum odına ḳan yaşile șu seper gözüm

İlā cigerde ḳan ḳurudı gözde nem ḳanı

....

Sulțān Muhammed ol kim idi şehriyār-ı dīn

Anuñile müreffeh idi rūzigār-1 dīn

.....

Ḥaḳdur ecel egerçi aña hayf yoḳ veli

Hayfum aña gelür ki nev-cuvānidi

….

Şehzāde Şeh Murād ki ḳāyim maḳāmıdur

Taḩt-1 sa'̄ādet üzre şeh-i tācdār ḳ̂l

…

Bāḳi ḳapuda cümle-i erkān-1 devletin

Yirlü yirinde devletile pāyidār ḳıl

Dâê̂’nin II. Murad için yazdığı biri büyük ikisi küçük üç kasideden onun yeni hükümdarla ilişkileri konusunda pek birşey öğrenmiyoruz. Dâê̂, II. Murad'a 'Ażudu'd-devle lakabı ile sesleniyor. Memleketin ona yedinci atadan miras olduğunu söylüyor ve ona genç olduğunu hatırlattıktan sonra yaşlı olan kendisinin öğüdünü tutarak, içip eğlenmesini tavsiye ediyor:

110 F. K. Timurtaş, "Ahmed-i Dâç" TD III (1954), s. 427; 1. H. Ertaylan, Ahmed-i Dâci, s. 27 .

111 Kahire yazmasi, yk. 32 a, beyit $9-10$; yk. 32 b, beyit 8 ; yk. 33 a, beyit 3 ; yk. 33 b, beyit 10, 13.

112 Kahire yazmasi, yk. 4 b, 1-2, 11-13; yk. 5 b, 10-12, 16 . 
Cimşĩd-i duvum 'aḳlile İskender-i sૂānī112

'İzzile 'alādan

Sultān-1 'Ażdu'd-devle113 Murād ibni Muhammed

Şāhenşeh-i ac $\mathbf{a}^{\mathbf{C}}$ ẓam

Mevrūs añadur memleketüñ kevn ü mekānı

Yidinci atadan

Luțfile gö ñül Ka'belerin yed-i 'ațāsı

İ̉ịsān u keremde

Şâkirdür anuñ nicmetine Ḳāżĩ vü dānî

Küll-i gurabādan

Devrãn çu senüñdür bugün iy rūḥ̂-1 cuvān-baht

Gel pir ögüdin dut

Kim 'İ̧ ile hoş geçse yig ol 'ömr-i cuvānī

Zevkịile șafādan

Dā'ì kim oḳur devletüñüñ medh ü ducāsın

İhläșile her dem

Nicmetlerüñüñ şükrinedür zikr-i lisānı

Envāe-1 șenādan

Dâê̂ divanında bir de Hamza Paşa için mersiye var. Kimliğini kesin olarak bilmediğimiz bu kişinin Amasyalı Beyezid Paşa'nın kardeşi, 1426 yılında Anadolu Beylerbeyi olan, Sicill-i Osmanîye bakılırsa II. Murad'ın ilk saltanat yıllarında ölen ${ }^{114}$ Hamza Paşa olduğunu sanıyoruz ${ }^{115}$. Dâê̂, başarılı mersiyesinde ona vezir-i muhteşem, mir-i muhterem, emin-i devlet $\ddot{u}$ din, Paşa-yı kamuran ve Hamza Bey diyor ve onu övüyor:

Kanı vezir-i muhteșem ü mir-i muhterem ${ }^{116}$

K'andan oldı häkmmile fermān (-1) rūzigār

113 Metinde "Ażdu'd-devle" olarak harekelenmiş bulunan kelimerin "cażudu'd-devle" olması gerekirse de her iki şekilde de vezne uymuyor.

114 Mehmed Süreyyâ, Sicill-i Osmanî, c. II, s. 251.

115 Şeyhł'nin de bu Hamza Bey'in düğünü dolayısıyla yazılmıș bir kasidesinin oluşu bize onun şairlerle ilgilendiğini gösteriyor, bkz., F. K. Timurtaş, Şeyhî, Hayatı ve Eserleri, Eserlerinden Seçmeler, Edebiyat Fakültesi Basımevi (İstanbul) 1968, s. 167-169.

116 Kahire yazması, yk. 19 a, beyit 5-6 8; yk. 19 b, beyit 14 ; yk. 20 a, beyit 7 ; yk. 20 b, beyit $5-7.53$ beyitlik bu mersiyenin değişik yerlerinden alınan sekizer beyitlik iki parça ve yedi 
Ol ḳanı kim elindeyidi hill ${ }^{117}$ ü 'aḳd-i mülk

Andan țutardı defter ü divānı rūzigār

Pāşā-yı kāmurān-ı vefãdār Ḥamza Beg

Vardı civār-ı raḥmete țāvūs-i sidre tek

$\cdots$

Dün Ḥaḳ'dan ol ki raḥmetidi luṭfidi bize

Ismarladuk şefācatile bugün uş Ḥaḳ’a

Şāhā saña vașiyyetüm oldur unutmagìl

Kim ben ḳuluñı yād idesin bir dữāyile

......

Pāşā'ya Ḥaḳ kerämetile raḥmet eylesün

Yatdugì yir hadīka-i dārü's-selām ola

Kabrini nūr-1 raḥmetile rūşen eylesün

Uçmaḳ içinde menzili cālī-maḳām ola

Ol yirde yatduginca şehā 'ümr ü devletüñ

Yirlü yirinde devletile şād-kām ola

Divanda ayruca, gene kimliğini kesin olarak bilmediğimiz Paşa Sultan adında birisi için yazılmış gazel biçiminde bir övgü var ${ }^{118}$. Bundan başka sık sık büyük bir coşkunlukla rindane şiirler yazıp, zahide çatan Dâê, yer yer zamanının güzel delikanlılarından da söz ediyor. Hasan, Hızır, Mustafa, Yusuf, Ahmed, Karagöz, Dilaram Efendi bunlar arasında yer alyyorlar:

Ol șūreti gör sīretile isme müsemmā $\bar{a}^{119}$

Hem adı Ḥasan vechi hasen hulḳ̣ hasendür

beyitlik bir parça Burdur yazmasında, bir mersiyeden alındıkların gösteren herhangi bir iz taşımadan, gazeller arasında karşımıza çıkıyorlar, bkz., Kahire yazması, yk. 20 b. beyit 1-3, 9-12; krş. İ. H. Ertaylan, Ahmed-i Dấ (Tıpkbasım), s. 20 beyit 1-8. Kahire yazması, yk. 19 b, beyit 6-13; krş. 1. H. Ertaylan, Ahmed-i Dấi (Tıpkabasım), s. 50, beyit 3-10. Kahire yazması, yk. 19 a, beyit 9-14; yk. 19 b, beyit 1; krş. İ. H. Ertaylan, Ahmed-i Dâĉ (Tupkabasım), s. 82, beyit 3-9. Bizim burada verdiğimiz beyitlerin hiç birisi Burdur yazmasında bulunmuyor.

117 Kelime "ḥall" yerine metinde "ḥll ü akd" olarak harekelenmiştir.

118 İ. H. Ertaylan, Ahmed-i Dậ, Mutâyebât (Trpkabasım), s. 295; krş. Kahire yazması, yk. $120 \mathrm{~b}$, beyit $4-8$.

119 Kahire yazması, yk. 84 b, beyit 6 . 
Çun senüñ la $\mathrm{li}$ lebündür cānuma cān arturan ${ }^{120}$

Olmasın sensüz cihānda bir nefes cānum Hुıżır

Ben bu hasretden ölürsem derd içinde el-firāḳ

Hak bilür kim boynuñadur șer Gile kanum Hıżır

İy cān içinde cāncugazum dilrübācuğum ${ }^{121}$

Cāndan 'azĩz sevgülüce Mușțafācugium

Beñzer cemāl ü ḥüsnile çun cāna Mușțafā122

Cãnlar fidt̂ cemālüñe cānāne Mușțafã

Melāḥat Mıṣrına sensin bugün uş Yūsuf-ı șānīi23

Keremde Hātim-i ${ }^{124}$ Țay'sın sehāvet iẹre kān Yūsuf

Hūublar içre şehānedür Karagöz $\mathrm{z}^{125}$

Baḳışı āhuvānedür Karagöz

Çoḳ ḳara ḳaşlu var ala gözlï

Kamusından yigānedür Karagöz

Cānum çu seni sevdi Dilärām Efendi ${ }^{126}$

Sensüz idemez cān u dil ārām Efendi

Dâê̂ divanının tam yazmasından elde edilen, Dâề'nin hayatı, çevresi ve karıștığı olaylarla ilgili bilgiler bunlar. Bunları ve burada değinilen, Dâê̂ ve eserleri ile ilgili önemli noktaları kısa ve toplu olarak bir daha sayalım:

Artık elde Dâê̂ divanının tam bir yazması bulunmaktadır. Bu yazmadaki beyit sayısı Burdur yazmasının bir katıdır.

Divandan Dâ'̂̀’nin doğum yeri, yılı ve öğrenimi ile ilgili yeni birşey öğrenilmiyor, Aydın ve Germiyan'la ilgili şiirlerin de olmayıșı onun bu çevrelerle ilişkileri konusunda tereddütler yarattığı gibi bu konuyla ilgili yargı larda çok ihtiyatlı olmayı gerektiriyor.

\footnotetext{
120 Kahire yazması, yk. 93 a, beyit 9-10.

120 Kahire yazmas1, yk. 93 a, beyit 9-10

121 Kahire yazması, yk. 60 a, beyit 8 .

122 Kahire yazmasi, yk. 92 b, beyit 3 .

123 Kahire yazması, yk. 81, b, beyit 3 .

124 "Ḥātem" metinde "Hुãtim" olarak yazılmış ve harekelenmiştir.

125 Kahire yazmas1, yk. 112 a, beyit 10-11.

126 Kahire yazmas1, yk. 95 a, beyit 6 .
} 
Çengnâme, Ali Paşa'nın ölümünden sekiz ay önce bitirildiği için, yalnız Çengnâme'ye dayanarak, orada adı geçen Alaeddin Mehmed Paşa'nın Ali Paşa öldükten sonra Emir Süleyman'a vezirâzam olduğu söylenemez. Dâê̂ şiirlerinde Ali Paşa'nın ölümünü pek önemsemiyor. Ali Paşa ile arasının çok iyi olmaması ihtimali kuvvetlidir.

Emir Süleyman Anadolu'da hüküm sürdüğü sıralarda, Dâề de onun yanmdadır ve Emir Süleyman Rumeli'ye dönünce Dâ'î de Rumeli'ye gider. Emir Süleyman öldürüldüğ̈̈̈nde Dâê̂, Rumeli'dedir. Emir Süleyman, Dâ'î̀yi genel olarak korumuş, ona iyi ve eli açık davranmıştır. Yalnız, bilinmeyen bir nedenle Dâcî'den uzak durup, ona bir süre pek yüz vermediği de olmuş Emir Süleyman devrinde belki de kadılık yapmıştır. Bir şiiri, Emir Süleyman'ın ona verdiği bir köyün vakıf gelirini almasına engel olduğu için zamanın kazaskeri ile arasının açıldığını gösteriyor.

Dâê̂'nin Emir Süleyman için yazdığı şiirlerde içki ve eğlence ile taht kavgasının izleri çok geniş ve önemli bir yer tutuyor. Dâĉ̀'nin ayrı bir eseri olarak bilinen Mutâyebât da divandan seçilme şiirlerden başka birşey değildir.

Dâê̂, Rumeli'de Emir Süleyman'in ölümünden sonra Musa Çelebi'ye, onun ölümü üzerine de Mehmed Çelebi'ye katılmış ve o sıralarda Farsça divanını Osmancıklı İmamzade Halil Paşa'ya değil, Amasyalı Hacı Halil Paşa'ya sunmuştur.

Dâê̂’nin Mehmed Çelebi için yazdı̆̆ı ilk şiirlerde Mehmed Çelebi'nin saltanatı ele geçirişinin izleri görülür. Dâ'î, bir süre sonra beş yıl için Mehmed Çelebi'nin yanından ayrılmış, çeşitli yerleri gezmiş ve geri dönmüşsür. Ne zaman olduğu belli değil, ama bir ara Dimetoka'ya şehzade eğitimi için gönderilmiştir. Dâề, gezdiği yerler arasında Rumeli, Bursa ve Mihaliç'ten başka, Dimetoka, Erzincan ve Akçakoyunlu'yu da sayıyor. Bir şiirinden Mehmed Çelebi'nin bir saray yaptırdığını öğreniyoruz.

Dâê, II. Murad'in ilk saltanat yllarında hayattadır. Mehmed Çelebi için yazdığı mersiye ve II. Murad adına yazdığı kasideler, bu konuda şimdiye kadar eksik olan kesin belgeler olarak saylabilirler.

Kahire yazmasında bulunan mersiyelerden birisinin kendisi için yazıldığı Hamza Bey'in 1426 da Beylerbeyi olan, Şeyhî’nin de kendisi için şiir yazdığı Hamza Bey olması ihtimali kuvvetlidir.

Divanda Hasan, Hızır, Mustafa, Yusuf, Karagöz, Dilaram Efendi gibi zamanın güzel delikanlılarından da söz ediliyor.

Bütün bunlar göz önüne alınarak, Dấî ile ilgili bilgilerimizin, Kahire yazması ortaya ફ̧ıktıktan sonra, eskisine oranla küçümsenemeyecek ölçüde genişlemiş olduğu söylenebilir. 